\title{
MOTIVATION AND ELECTRONIC MEDIA IN LSP TRANSLATION TEACHING
}

\author{
Ljubica KORDIĆ, PhD, Associate Professor \\ University of Osijek, \\ Faculty of Law Osijek, Croatia \\ kljubica@pravos.hr
}

ORCID: http://orcid.org/0000-0002-2900-7906

\begin{abstract}
Expansion of IT-media in every field of human activity is one of the essential characteristics of modern time. This paper aims at presenting the role of electronic media in teaching translation in the field of law at the University of Osijek, Croatia, and analysing their impact on the motivation of the target group of students in the teaching process. The paper endeavours to provide some insight into the modern teaching practice and to analyse the interconnectedness of the use of electronic media and student motivation rather than to present some empirical research in the field. In the first part of the paper, a theoretical approach to teaching legal translation today is offered. In the main part, teaching legal translation by using modern media is presented on the examples of the Lifelong Learning Programme for LawyerLinguists at the Faculty of Law Osijek, and the course on legal translation within the German Language and Literature Studies at the Faculty of Humanities and Social Sciences of Osijek. The usage of electronic media in
\end{abstract}


translation teaching is discussed with reference to the courses Introduction to the Theory of Legal Translation and Online Translation Tools and EU Vocabulary. Specific types of online materials, translation tools and sources are discussed from the point of view of student motivation. New media are also discussed from the perspective of their efficiency at different stages of translation teaching. In the concluding part, application of modern technologies in teaching legal translation is compared with other teaching methods, approaches and techniques. Finally, the author questions using IT as motivation tools in the higher education teaching discourse and argues for application of "moderate approach" in the teaching of legal translation.

Key words: Electronic media; motivation; the language of law; teaching legal translation

\title{
MOTYWACJA I MEDIA ELEKTRONICZNE W NAUCZANIU TEUMACZEŃ SPECJALISTYCZNYCH
}

\begin{abstract}
Abstrakt: Ekspansja mediów informatycznych w każdej dziedzinie życia jest jedną z podstawowych cech współczesnego życia. Niniejszy artykuł ma na celu przedstawienie roli mediów elektronicznych w nauczaniu przekładu prawniczego na Uniwersytecie w Osijek w Chorwacji oraz przeanalizowanie ich wpływu na motywację grupy docelowej studentów w procesie nauczania. Autorka stara się przedstawić nowoczesną praktykę dydaktyczną i przeanalizować wzajemne powiązania korzystania z mediów elektronicznych i motywację studentów. W pierwszej części artykułu zaproponowano teoretyczne podejście do nauczania tłumaczenia prawniczego. Na przykładach programu „Lifelong Learning Programme for Lawyer-Linguists" na Wydziale Prawa Osijek oraz kursu tłumaczenia prawniczego w ramach „German Language and Literature Studies” na Wydziale Nauk Humanistycznych i Społecznych w Osijek autorka prezentuje nauczanie thumaczenia prawniczego przy użyciu nowoczesnych mediów. Wykorzystanie mediów elektronicznych w nauczaniu tłumaczeń omawia się w odniesieniu do kursów „Wprowadzenie do teorii tłumaczenia prawniczego i narzędzi tłumaczenia online oraz słownictwa UE”. Konkretne rodzaje materiałów online, narzędzi tłumaczeniowych i źródeł omawia się z punktu widzenia motywacji studentów. Nowe media są również analizowane pod kątem ich skuteczności na różnych etapach nauczania przekładu. Podsumowując, zastosowanie nowoczesnych technologii w nauczaniu tłumaczenia prawniczego porównuje się z innymi metodami, podejściami i technikami nauczania. $\mathrm{Na}$ koniec autorka kwestionuje zasadność
\end{abstract}


wykorzystania narzędzi IT jako motywatorów w dyskursie dydaktycznym szkolnictwa wyższego i opowiada się za zastosowaniem „umiarkowanego podejścia” w nauczaniu tłumaczenia prawniczego.

Słowa klucze: media elektroniczne; motywacja; język prawa; nauczanie

\section{MOTIVACIJA I ELEKTRONSKI MEDIJI U NASTAVI PREVOĐENJA}

Sažetak: Širenje i primjena elektronskih medija na svim područjima ljudske djelatnosti jedno je od osnovnih obilježja modernoga doba. Cilj je ovoga rada prikazati njihovu ulogu u podučavanju pravnoga prevođenja na Sveučilištu u Osijeku, Hrvatska, te analizirati njihov utjecaj na motivaciju studenata u nastavnom procesu. U prvom se dijelu rada nudi pregled teorijskih pristupa podučavanju prevođenja u području jezika prava. Glavni je dio rada fokusiran na uporabu elektronskih medija u podučavanju pravnoga prevođenja u okviru Programa cjeloživotnog obrazovanja za pravnike-lingviste na Pravnom fakultetu Osijek na primjeru predmeta Introduction to the Theory of Legal Translation i Online Translation Tools and EU Vocabulary. Raspravlja se specifičnim vrstama nastavnih materijala i alata dostupnih online s obzirom na njihovu motivacijsku ulogu u podučavanju prevođenja. Uloga elektronskih medija također se diskutira iz perspektive njihove učinkovitosti u različitim etapama nastavnoga procesa. U zaključnom se dijelu rada primjena modernih tehnologija u nastavi uspoređuje s drugim nastavnim metodama, pristupima I tehnikama. Na kraju autorica propitkuje uporabu elektronskih medija kao motivacijskog sredstva u visokoškolskoj nastavi i zagovara primjenu "umjerenog pristupa" u podučavanju pravnoga prevođenja.

Ključne riječi: elektronski mediji; motivacija; jezik prava; podučavanje pravnog prevođenja

\section{Introduction}

The aim of this paper is to present the application of electronic media in teaching translation in the field of law in formal and non-formal education in Croatian higher education institutions on the example of the University of Osijek, with specific reference to the motivational role of computer technology in attaining the outlined teaching 
outcomes. The paper is focused on the analysis of teaching translation skills in non-formal education at the Faculty of Law (the Lifelong Learning Programme for Lawyer-Linguists), University of Osijek, and formal education within the Translation studies of the Faculty of Humanities and Social Sciences, University of Osijek. Although new media and information technologies are indispensable in the translation process today, the main idea that will be elaborated in the paper is that best results in teaching legal translation can be achieved by active interconnectedness of theoretical and practical knowledge transferred in a dynamic teaching process, in which different learnerdirected methods including information technologies and the face-toface method are combined to motivate students. This specifically implies that the role of an enthusiastic teacher, experienced in the field of legal language(s) and legal translation, is of utmost importance as a motivational factor. Before presenting the methodological approach to teaching translation at the two higher education institutions, theoretical background on translation in the field of law and the role of motivation in teaching discourse will be briefly presented.

Crucial for the approach to teaching translation in the field of law is developing students' awareness of specific features of this type of translation in reference to translation in other professional fields. Publications by esteemed Croatian linguist and translator Susan Šarčević are used as basic reference literature in the field of legal translation. Her worldwide known definition of legal translation as "an act of communication in the mechanism of law which has far-reaching consequences and sometimes irreversible effects that can even endanger peace and stability" is used as moto both in formal and nonformal programmes carried out at the University of Osijek (Šarčević 2000). This definition of intriguing character is usually seen by students as challenging and highly motivating. Students should also be introduced to the cultural aspect of legal translation as one of its specific features distinguishing it from translation in other professional fields. Accordingly, they should be informed about ideas and research work by Reiß and Vermeer (Reiß and Vermeer 1984), known for their functionalistic approach to legal translation, in which the interdependence of the translation method and the function of the text represent a basic principle. Another essential principle of this theory is the constant awareness that cultural differences between the source language and culture and the target language and culture represent indispensable elements of a reliable translation of legal texts. 


\section{Comparative Legilinguistics 40/2019}

As legal contents are transferred from one culture and legal system into another, a translation in the field of law is often referred to as a specific type of cultural transfer (Hegenbarth 1982). Because of this, the question of relativity of equivalence in legal translation should be put forward.

A special place in teaching legal translation belongs to the development of competences that qualify a good legal translator. Kelly has summed up those competences into one complex translation competence and determined it as a "construct consisting of knowledge, skills and attitudes necessary for translation task realization"(Kelly 2005: 162). The translation competence is comprised of the following set of competences: communicative, textual, cultural and intercultural competences, subject-area competence, professional, instrumental, psycho-physiological, strategic, and interpersonal competences. According to Šarčević, a competent translator in the field of law should additionally master specific types of knowledge and skills closely connected with the legal profession: knowledge of legal terminology, in-depth understanding of logical principles, logical reasoning, the abilities of problem solving and of text analysis, and the knowledge of the target and source legal systems. As Šarčević stated, this clearly implies that "a heavy burden of responsibility rests on the shoulders of legal translators" (Šarčević 1997: 13).

Developing translation competences represents a challenging job that involves a full engagement of a competent teacher, who is able and ready to apply all available teaching tools and materials in the teaching process, including modern information technology. In this process, motivating students is of utmost importance. Two basic types of motivation are intrinsic and extrinsic motivation. In relation to the use of IT in teaching translation, intrinsic motivation is fulfilled by the fact that the skills developed within the course enable students' better employment chances. Extrinsic motivation can be achieved by offering students interconnectedness of theory and practice by using different teaching tools and methods, including IT. In my opinion, there are three basic methods of achieving extrinsic motivation in translation teaching: a) in face-to-face teacher-learner approach, by offering interesting facts and examples, and by problem solving and research tasks, b) by efficient use of computer technologies (Internet, skype, informal social network groups, translation tools and online 
terminology database), and c) by teacher's personal competence, expertise and enthusiasm for the subject.

\section{Electronic Media and Legal Translation in Education: the University of Osijek Case Study}

\subsection{Teaching Legal Translation in Croatia - a Short Overview}

The awareness of the importance of legal translation has grown in Croatia since its accession to the EU, but not to an extent that it deserves. Today, teaching legal translation in Croatia is carried out within Translation Studies at the Faculties of Humanities and Social Sciences of the universities of Zagreb, Rijeka, Osijek, Split, Zadar and Pula. As a rule, legal translation is taught at the MA level mostly as part of the course "Translation of Specialized Texts". Translation in the field of law is just one of the specialized areas within that course, with the terminology, structures and phraseology prompted from the translated text. Only in two institutions, the Faculty of Humanities and Social Sciences in Zagreb and the Faculty of Humanities and Social Sciences in Osijek, the theoretical course is followed by translation skills seminars. Both institutions offer translation courses as elective courses in the field of law, carried out 15 to a maximum of 30 hours a year, either as a compulsory or elective course. At the Faculty of Humanities and Social Sciences in Osijek, the course is offered only in the English and German language. At the Faculty of Humanities and Social Sciences in Zagreb, there is also a Postgraduate Specialist Study Programme in Translation, lasting for 2 semesters, allocated with 60 ECTS, and dealing with specific features of specialized translation in general. It is a compulsory course delivered in 10 teaching units in total. Additionally, at the Faculties of Law of the Universities of Zagreb and Osijek, since 2012 (a year before the Croatian accession to the EU), lifelong learning programmes focused on legal translation have been developed as non-formal types of university education. In the main part of this paper, the Lifelong 
Learning Programme for Lawyer-Linguists at the Faculty of Law, University of Osijek shall be presented with specific reference to teaching methodology and computer programmes used in the courses Online Translation Tools and EU Vocabulary and Introduction the Theory of Legal Translation and Terminology. After presenting these courses and the role of IT-media in their delivery, the elective course Linguistic Features and Translation of the German Language of Law, delivered at the Faculty of Humanities and Social Sciences in Osijek will be briefly elaborated with an emphasis on electronic media as a part of teaching methodology.

\subsection{Lifelong Learning Programme for Lawyer-Linguists at the Faculty of Law, University of Osijek}

The Strategy of Josip Juraj Strossmayer University of Osijek for the period 2010-2020 promotes lifelong learning programmes as nonformal ways of education (2011: 54). Following this goal, in the accession period of the Republic of Croatia to the EU and its labour market, the Chair of Foreign Languages of the Faculty has developed a Lifelong Learning Programme for Lawyer Linguists as a direct response to new economic prospects and employment chances opened to Croatian lawyers on the EU labour market. The programme was accredited by the Senate of the University of Osijek in 2012. It is comprised of seven courses encompassing 160 teaching hours, which are allocated 22 ECTS credits in total. Attendants are graduate lawyers who have thoroughly mastered two foreign languages English and German. Before enrolling into the programme, they must prove their language skills by submitting corresponding certificates. The programme is carried out in three months (winter semester) and financed by a participant fee payable in 3 instalments. Upon passing all exams, attendants obtain certificates signed by the Dean of the Faculty. The Programme encompasses the following courses: Introduction to the Theory of Legal Translation and Terminology, Exercises in Legal Translation - English Language, Exercises in Legal Translation - German Language, Introduction to the French Language of Law, Croatian Language for Lawyer-Linguists, Introduction to the EU Law, and Online Translation Tools and EU 
Vocabulary. In developing the courses, the basic idea was that the theory of legal translation should be actively and in the purposeful way interwoven with the knowledge that will be applied in the practical translation exercises, which are carried out by using different methods and techniques, including electronic media. This is in accordance with the well-known statement by Susan Šarčević, that a theory of legal translation must be practice-oriented to be effective (Šarčević 2000: 271). The essential idea of the programme was that in its theoretical part, which is focused on common and specific features of English, German and Croatian languages of law, should be delivered by a comparative approach to these three languages and illustrated by numerous examples. In two exercises (seminars) on legal translation from English and/or from German, practical translation from English to Croatian and from German to Croatian is practiced based on the previously acquired theoretical knowledge. In all courses, modern teaching methods are implemented, including PowerPoint presentations, search for original legal documents in English and in German available online, and using the online EU law dictionaries.

In the following part of the paper, the methodological approach and the application of information technologies within the courses Introduction to the Theory of Legal Translation and Terminology, and Online Translation Tools and EU Vocabulary will be presented, as these two courses are focused on legal translation. They include theoretical and practical elements of translation teaching and in each of them computer technologies are used in a specific way.

\subsubsection{The Course Introduction to the Theory of Legal Translation and Terminology}

The course aims to transfer the basic knowledge of English, German and Croatian legal languages to students who are equipped with little or no theoretical linguistic knowledge, to instruct them in specific features of legal translation from English and German into Croatian, and to equip them with basic skills and competences in legal translation. These competences encompass the understanding of legal principles, logical reasoning, the ability of problem-solving and text 
analysis, and, finally, to develop students' ability to apply theoretical knowledge in the translation process. The course is delivered in the form of eight basic topics by using a comparative approach, in a way that every linguistic phenomenon relevant for translation is explained and illustrated by examples typical of the English, German and Croatian languages of law. Emphasis is put on linguistic, legal and cultural similarities and differences. Lectures are theoretically founded on the work of Heikke Mattila and Susan Šarčević in the field of Legal English and of Katarina Reiß, Hans Vermeer, Radegundis Stolze and Erich Prunc in the field of Legal German. The basic reference for the Croatian language of the law is the book by the author of this paper titled "Legal linguistics - A Synergy of the Language and Law" (Kordić 2015). Some examples that are used as illustrations of specific linguistic phenomena are also excerpted from the author's research papers published in the last 20 years in the sphere of the three languages of law and legal translation, and from her long teaching and translation experience in English and German languages of law.

The methodological approach includes the face-to-face method combined with electronic media. This approach within the course Introduction to the Theory of Legal Translation and Terminology will be illustrated by a detailed presentation of two lectures as examples, with a short overview of other sessions. To motivate students and to increase their interest in legal translation, the introductory lecture was dedicated to specific features of the legalese, and poetic elements in legal phrases and expressions, so it was titled Poetry of the Language of Law. Intriguing and provocative in its title, the topic awakes curiosity and interest in students. It deals with poetic elements in the language of law and is opened by quoting the title of the scientific paper "On the Poetry of the Language of Law", published by Jakob Grimm back in 1816 in Zeitschrift für geschichtliche Rechtwissenschaft in which metaphors, comparisons, and symbolism as poetic figures were observed and analysed in Germanic customary law. Based on the idea of that paper, students are asked to analyse in pairs a modern legal text in English from the EU law and English common law, to discover elements of metaphor, symbolism, personifications and alliterations. The second half of the lecture is focused on comparative analysis of examples of metaphor,

\footnotetext{
${ }^{1}$ Translated from German by the author of this paper
} 
alliteration, personification, symbols, doublets and/or tautologies in the German, English and Croatian languages of law based on the teacher's research (Kordić 2010). For example, as an illustration for metaphors in the three languages, some typical collocations are mentioned, like legal remedy/ Rechtsmittel/ pravni lijek; burden of evidence/ Beweislast. These examples also give rise to an analysis of a possible theoretical approach to translation, and the exploration of the existence or non-existence of translation equivalence between these terms. This type of discussion is especially interesting in the case of doublets, as some of them have equivalents only in one foreign language, some in two languages, and in some cases, there is no equivalence at all. Doublets are offered in English and German, and students are asked to find their correspondents in the Croatian language:

German

Null und nichtig

Zur Last legen/ zur Last liegen

Leib und Leben

Notwehr und Notstand

Verbrechen und Vergehen
English

null and void

last will and testament

law and order

terms and conditions

peace and order

Students are also asked to research which of these structures in English also function as alliterations in German and Croatian, and which are pleonasms or/and tautologies. As a homework assignment, students are asked to find a specific legal text in EU law on the EurLex Internet platform. In presenting the topic, PowerPoint is used, and to reach the EU legal text, students surf the Web.

The next session is dedicated to general features of the language(s) of law. Each of them is discussed thoroughly and illustrated by examples from legal texts in English, German and Croatian languages. Special attention is paid to the legal style, which is claimed to be clear, precise, exact, objective, but at the same time "all-inclusive and ambiguous" (Bhatia 2004). It can be stated that the style of legal language is a contradiction per se. This idea has been pointed out and discussed by several European linguists interested in the language of the law. One of them, a German Dietrich Busse, even stated that the conflict not only was at the core of law and justice but also the fundamental feature of the language of law (Busse 1999). The topic itself is interesting and motivating for students. To make the 
lecture more interactive and motivate students to additional activity, they are asked to apply their knowledge at home by translating one EU-law text. They are asked to discover the discussed stylistic features in the text while translating it and to highlight the problems or doubts arising during the translation process. The finished translation is sent by e-mail to the teacher in four days, so that teacher's comments and corrections in track-changes mode could be sent back before the next session.

The third session is more specific in its scope and deals with Linguistic features of the English, German and Croatian languages of law. These features are discussed in reference to every level of linguistic analysis: lexis and semantics, morphology and grammar structures, word formation systems of the three languages, the syntax of the legalese in the three languages and specific stylistic features for each language, with a wealth of examples to be discussed and compared. The following session is focused on translation as communication, with specific reference to the role of the translator in the triangle text producer-translator-text receiver. As the most appropriate approach to legal translation, the functionalist approach based on the skopos-theory is discussed in relation to the principle Enttrohnung des Ausgangstextes developed by Erich Prunc. For translation in the field of Legal English, the ideas and principles developed by Susan Šarčević and Heikke Mattila are transferred to students, illustrated by examples and implemented in translation tasks. In every session, computer technology is used to present the topic and examples, combined with an interactive face-to-face approach. Problem questions are used as a motivating technique at the beginning or in closing the lecture. For example, in the unit dealing with translation as a communication process, students are asked to discuss the question "What is the smallest (and basic) unit of translation?" The fifth session goes deeper into the topic of legal translation and deals with the specific methodology of legal translation with reference to the English, German and Croatian languages of law. The knowledge transferred is based on the theoretical approach by Šarčević (English), Prunc (German) and publications on comparative research of Croatian, English and German languages of law by the author of this paper. Three basic factors of translation are discussed related to legal translation: habitus, field and capital. Special attention is paid to the notion of the relativity of equivalence, within which three types of equivalence are illustrated in English, German, and 


\section{Ljubica Kordić: Motivation and Electronic Media in LSP...}

Croatian. The session is concluded by a creative task for students to discuss the equivalence problem(s) while translating the term administration in several different contexts. As homework, students are asked in every session to translate a short legal text from English into Croatian and to send the translation by e-mail to the professor before the next session with comments and questions concerning different degrees of equivalence within the translation. In the next session, focused on the macro-to-micro-level-approach in legal translation, an EU law text is analysed from the aspect of its "embeddedness" in the source and the target cultures and legal systems. By following the functionalist translation principle, the steps in the translation process are discussed by using the structural approach, with special attention to phrases, collocations and polysemy terms, and questioning the equivalence of legal terms and concepts in the source and the target language. The seventh session is specifically dedicated to translating EU Law and EU terminology. Issues of congruency of EU terms are put forward, as well as EU law neologisms and structural rigidness of parallel EU texts with the goal of producing the equal legal effect in multiple translations. In the final part, by using PowerPoint, students are offered a comparative list of recommended standardized EU terms in English, German and Croatian. Accordingly, they are recommended to use glossaries, dictionaries and manuals of EU terminology available online. During the last meeting, "traps" in legal translation in the three languages are discussed, including all language phenomena that might cause misunderstandings and lead to wrong or inadequate translations. These phenomena are listed and illustrated by examples of translation from English into Croatian and from German into Croatian. Legal collocations and prepositional phrases in three languages are mostly used as illustrative examples, e.g.in conformity with/in compliance with; to enter /come into force; in Einklang stehen, in Kraft treten, as well as specific verb phrases, e.g. Entscheidung treffen, Berufung einlegen, lodge appeal, exercise duty. "Traps" for an inexperienced translator may also be the cases of internal and external polysemy, e.g. Einstellung, Leistung/ challenge, intelligence, cases of synonymy and homonymy, legal metaphors in three languages, etc. Conceptual and cultural differences between the common law system and the civil law system, including the problem of equivalence, represent another challenge for translators of legal texts. This can be well illustrated by the term law of torts and its equivalent in the civil law system, and by 
conceptual differences between the terms damage vs. damages, sue vs. prosecute in common law system and their functional equivalents in German and Croatian languages. At the closure of the course, one additional session is organized as a guest lecture of interactive character, given by an EU translator, who shares with the students his/her experience of working in the DGT- services of the EU.

\subsubsection{IT within the Course Online Translation Tools and EU Vocabulary}

This course is aimed at offering the students sources of information that should become a part of their personal capital and their habitus as translators. Within the 20 teaching hours, this course is focused on two practical tasks. The first is to instruct students on how to find, access and use legal terminology, information and documents in English as well as how to search databases in Croatian available online for the purpose of an adequate, reliable and functional legal translation. The second task is to inform the students on computerbased aids in translation (like AntConc programmes) and on the advantages and disadvantages of using the machine and computerassisted translation. Firstly, online sources used within this course will be briefly presented, followed by the main features of machine and machine-assisted translation as the second part of the course.

1. Interinstitutional style guide (http://publications.europa.eu/code/en/en-000100.htm) contains uniform stylistic rules and conventions which must be used by all the institutions, bodies, offices and agencies of the European Union. It is available in all EU languages. This database gives useful advice on protocol, official names of countries, institutions, currencies, languages, acronyms, etc., and can be downloaded free of charge at bookshop.europa.eu

\section{EUROVOC - Multilingual Thesaurus of the European Union} (http://eurovoc.europa.eu) is a multilingual, multidisciplinary thesaurus covering the activities of the EU managed by the Publication Office. It contains terms in EU languages (including Irish 
Gaelic, Albanian, Macedonian and Serbian). The scope of its users ranges from European Parliament, Publication Office, national and regional parliaments in Europe to national governments and private users. Other vocabulary sources recommended to students are EUdict - http://www.eudict.com/ and EUROSTAT, which encompasses EU terms and abbreviations (http://ec.europa.eu/eurostat/ramon/cybernews/abbreviations.htm).

3. EUR-Lex (http://eur-lex.europa.eu) is indispensable in teaching legal translation in EU law and the respective EU vocabulary. It is a well-known EU legal directory that provides free access in official EU languages to the authentic Official Journal of the European Union and to all EU treaties, directives, regulations, decisions, etc. It also enables insight into EU preparatory acts (legislative proposals, reports, green and white papers, etc.), the EU case law (judgements, orders, etc.), international agreements, EFTA documents and summaries of EU legislation explained in plain language. By accessing the EUR-Lex page, students get insight into national law of member states through the national legislation of every EU country (N-Lex) at http://eur-lex.europa.eu/n-lex/index_en, as well as into national implementing measures and national case-law. In case students need information or terminology from EU civil and commercial case law, they are also recommended to choose the database JURE containing EU judgments in civil and commercial cases. The JURE collection (Jurisdiction, recognition and enforcement of judgments) however, contains only judgements available in their original languages with summaries in English, French and German. In teaching legal translation, they can be used as examples of certain legal terms and their specific use in respective languages. Students are also informed about benefits of the links CORDIS http://cordis.europa.eu/ (Community Research and Development Information Service), which provides information on EU-funded research projects and their results, Ted (Tenders Electronic Daily) available at http://ted.europa.eu, and 'Supplement to the Official Journal' of the EU, containing public procurement tenders. Students are instructed in detail on how to navigate through the EU legislation database by using the Celex Number. This code number, composed of nine digits and one or two characters, is the easiest method of accessing the Official Journal of the EU. At first, students are instructed on how it is composed, how to understand and distinguish 
different Celex numbers, and then how to use specific Celex number in order to reach an original EU legal act. For the purpose of their concrete translation tasks, attendants are instructed on how to produce a Celex number to find a document they need (e.g. in order to search for legal facts or specific legal terms or phrases).

4. IPEX - The Platform for EU Inter-parliamentary Exchange, available at http://www.ipex.eu may also be of practical value for legal translators, so students are introduced to the practical benefits of this platform. It contains opinions of national parliaments on or about draft EU legislation, its primary function being to facilitate interparliamentary cooperation in the $\mathrm{EU}$ and to enable the interparliamentary electronic exchange of all EU-related information between parliaments of the EU member states. The platform contains information about parliamentary scrutiny in EU affairs, like subsidiarity issues and an updated calendar of scheduled interparliamentary meetings. The site also has forums for the exchange of views on topical issues, so it is a valuable source of information about the state of affairs in the EU and its member states. The prevailing part of IPEX makes a document database of relevant EU documents and corresponding documents from national parliaments, as well as draft legislative proposals, documents from the European Commission and information concerning the European Union. So by accessing this page, students learn where and how to find updated information on parliamentary issues and/or specific legal terminology from that field.

5. The European Union Open Data Portal is a very useful site offering all data on the EU that are freely available to the public, so legal and language experts can also access the requested data without previous registration. The platform offers numerous search options: from alphabetical search, search according to subject matter or subject group, the popularity of search topics, or according to source and the date of the information. The Portal offers access to other databases, such as CORDIS (EU-funded research projects database), Eurostat (statistical data from various domains within the EU), DORIE (collection of all documents issued by the European Commission), ESCO (European Skills, Competences, Qualifications and Occupations database). It also allows access to the EuroVoc as well as to the DGT-Translation memory, which is a valuable database for translators, containing legal sentences and their direct translations into 
24 languages of the EU. Attendants are instructed on how to use the most helpful features of the European Union Data Portal. Students are usually given homework assignments to search for specific information at this web site.

6. IATE (Inter-Active Terminology for Europe) http://www.iate.europa.eu - this database is a result of the project launched in 1999, aimed at creating EU's inter-institutional terminology database. IATE has been in use in EU institutions and agencies since 2004. It incorporates all of the existing terminology databases of the EU translation services into one interinstitutional database. Croatian EU law terminology is a constituent part of the collection. The IATE database is structured according to EU institutions and their specific scope of activities. It has been updated on a daily basis and has experienced substantive changes and developments in recent years. This database is of indispensable importance for legal translators and students, who are instructed in how to use all the possibilities offered on this platform.

Picture 1. http://www.iate.europa.eu

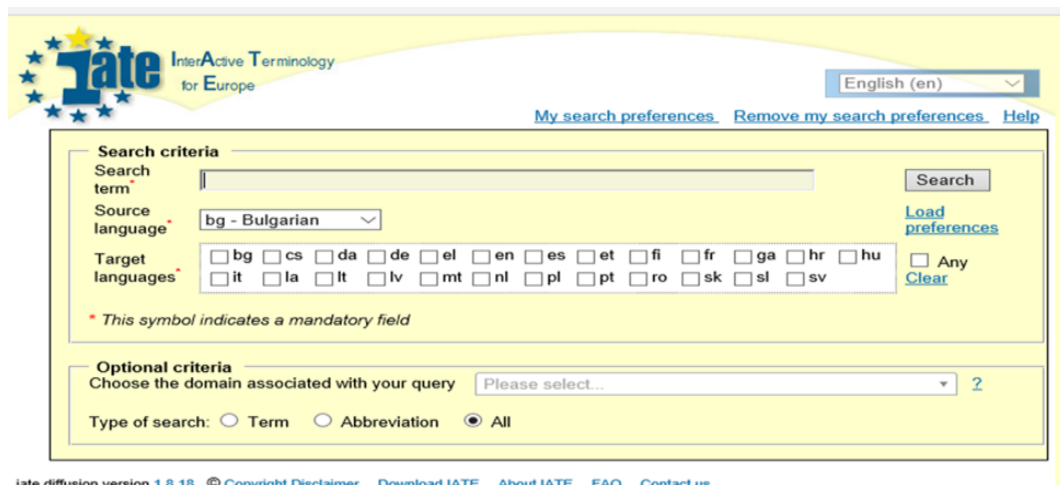

7. The TAIEX web-site can additionally provide useful information for Croatian students. TAIEX (Technical Assistance and Information Exchange) is an instrument of the European Commission managed by its Directorate General for Enlargement, its main task being to assist partner countries in harmonizing and implementing EU legislation. Beneficiaries and partner countries are Iceland, Turkey, FYR of Macedonia, Albania, Bosnia and Herzegovina, Montenegro, 
Serbia, Kosovo, the Turkish community in the north of Cyprus, Algeria, Armenia, Azerbaijan, Belarus, Egypt, Georgia, Israel, Jordan, Lebanon, Libya, Moldova, Morocco, Palestine, Syria, Tunisia and Ukraine. If translation refers to legislation of any of these countries, the data available at this platform may be useful.

Picture 2: TAIEX web-platform

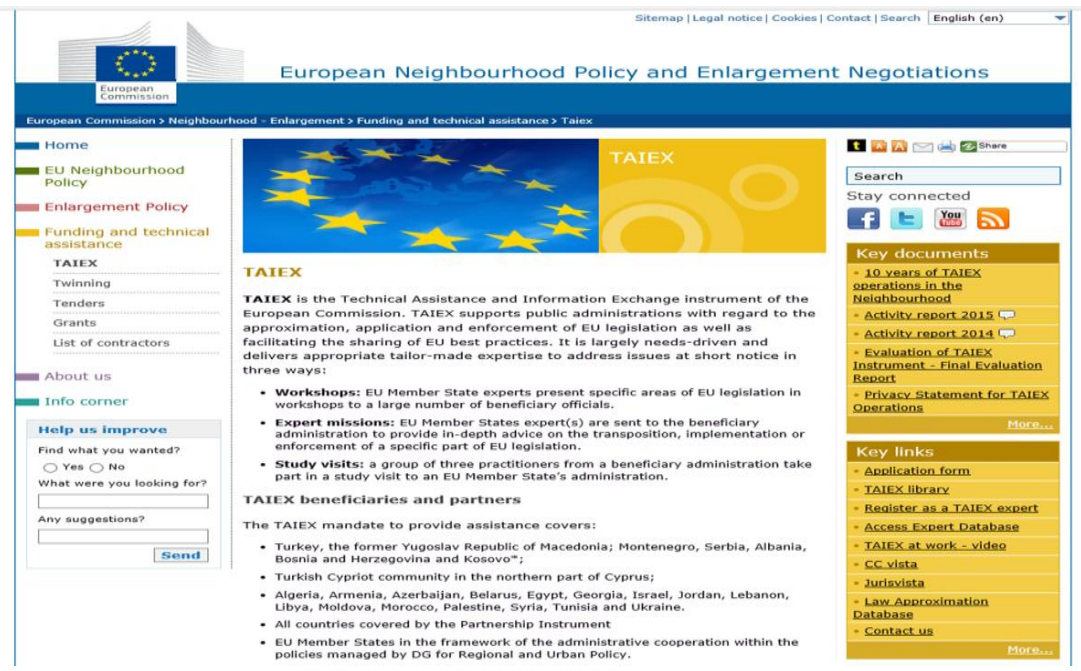

The final part of the course is focused on machine, respectively machine-assisted translation. Although machine translation was for years exposed to criticism, years of experience have resulted in substantial improvements to the service in some language pairs, e.g. English - German, English -French, French-German). As machine translation software is mostly oriented towards "big" languages, machine translation is still unavailable for the Croatian language, and programmes for machine-assisted translation including this language are very limited. Course attendants are informed about the advantages and disadvantages of machine translation tools, particularly about differences between machine translation and machine/computerassisted translation. Machine translation is understood as automatic translation from one language to another or translation automated by use of the computer translation process ${ }^{2}$. Machine-Assisted

${ }^{2}$ https://hpi.de/fileadmin/user_upload/fachgebiete/plattner/teaching/MachineTranslatio n/MT2015/MT01_Introduction.pdf 
Translation or Computer-Assisted Translation (CAT) is a translation process involving human activity and performed by using computer software to support and facilitate the translation process. A quick and efficient translation process and confidentiality of translation are highlighted as advantages of machine translation, while lack of superior exactness, lacking of authoritative control and inferior translation quality of texts with ambiguous words and sentences, along with the necessity of serious and detailed human work are seen as disadvantages. Students are further informed about Machine/Computer Assisted Translators that are free of charge: REVERSO (http://www.reverso.net/text_translation.aspx ?lang=EN), SYSTRAN (http://www.systransoft.com/), SDL Free Translation (http://www.freetranslation.com/). For lesser- used languages, commercial computer-assisted translation tools are out of reach, including Croatian, as these tools are very expensive for private users. Students are introduced to a software Neurotran, which is a translation software for English-Croatian/Croatian-English or German-Croatian and Croatian-German languages combinations. They are trained in every step of software application and in options of how to insert changes in the target text.

Pictures 3 and 4: Translation procedure with the Neurotran translation software

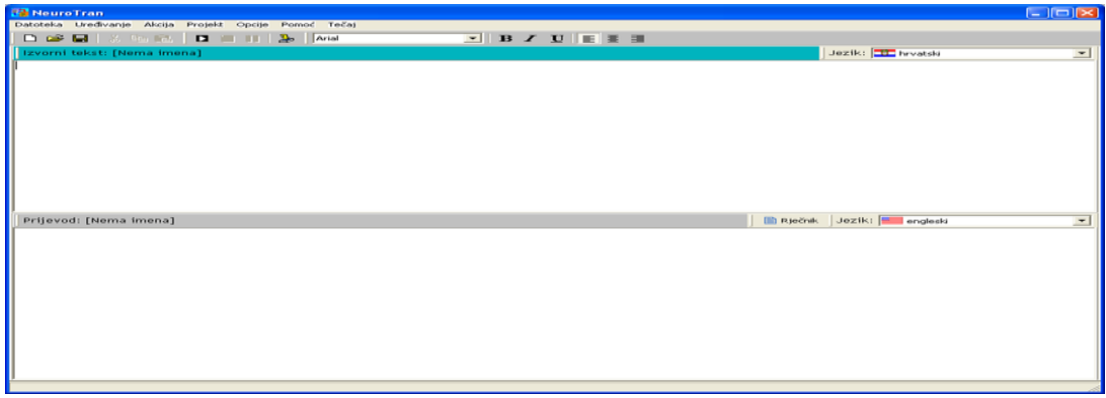




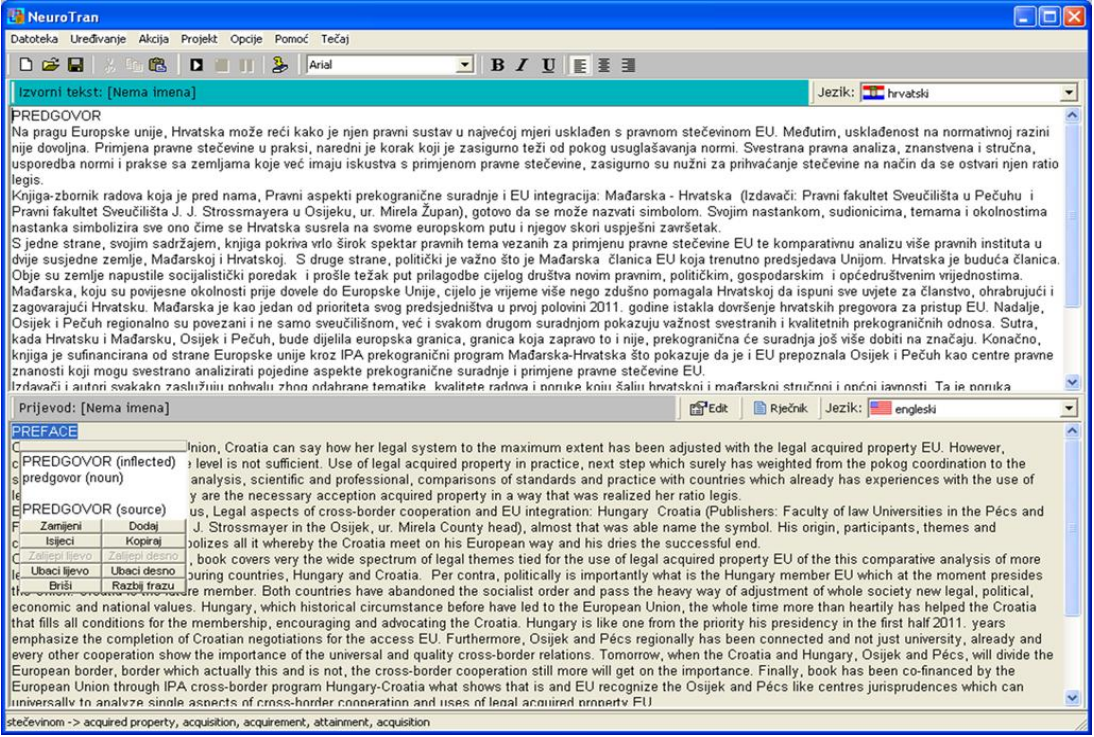

\subsection{The Faculty of Humanities and Social Sciences Osijek: The Course Linguistic Features and Translation of the German Language of Law and IT}

The course is delivered in 15 hours theory +15 hours training. The theoretical part is structured similarly as the theory course delivered within the Lifelong Learning Programme at the Faculty of Law Osijek, only with reference to German legalese. The teaching content is based on the work and ideas of Katarina Reiß, Hans Vermeer, Radegundis Stolze, Peter Sandrini, Erich Prunc and publications by the author of this paper. The practical part is dedicated to oral translations in classes, for which purpose the textbook for law students Rechtsdeutsch by Susan Šarčević is used as the main reference, with additional EU law documents from the Eur-Lex platform. The e-mail teacher-student correspondence functions mostly as a means for students to send their homework assignments to the teacher and for his/her feedback. In the next session, translations are discussed in the classroom in the face-to-face approach, with special reference to 
specific features of the German language of law and the equivalence problems in translation from German into Croatian and vice versa.

\section{Methods, Tools and Techniques in Translation Teaching and Student Motivation}

As it was shown, in the methodological approach to translation teaching, the face-to-face method is combined with electronic media as the teaching tools. Within the face-to-face method, problem questions are asked and creative tasks are given to students based on interesting and intriguing examples. To motivate students, a reference is made to historical language contacts between the three cultures, including interesting examples of the historical interconnectedness of German and Croatian legal terminology and phraseology. PowerPoint is used to present lectures and the Internet to access original EU legalization available online. IT is also used in student's individual work in classes or at home, as after every session students are given research assignments connected with specific translation problems. Students are encouraged to use their mobile phones in pair work during the lessons in order to exchange and analyse each other's solutions to specific translation tasks. When homework is related to the translation of a specific legal text, students are expected to send their translations per e-mail to the teacher who sends back his/her review in track-changes mode before the next session. The basic principle of the teaching approach is the active interconnectedness of the translation theory and practice, with strong involvement of the teacher as moderator and coordinator of teaching activities.

In decision-making on the methodology and teaching tools to be used in teaching translation on academic level, teachers must be aware of the fact that modern generations of students are a generation of the "digital natives", having grown up surrounded by computers, the Internet and mobile phones. Due to the intensive change in information technologies, the IT-founded communication has become a part of education at every level, so discourse framework is changing rapidly as well. Teachers are aware of the necessity of the greater flexibility to exploit the opportunities and challenges of new media in teaching, especially in order to motivate students. Motivation is an 
indispensable factor of the teaching discourse which "increases initiation of and persistence in activities; it also increases students' time on task" (Larson and Rusk 2011). No doubt that the use of information technologies can positively influence both intrinsic and extrinsic motivation and needs to be integrated into the course design. In teaching foreign languages, modern teaching approaches by using IT are implemented, like blended learning or e-learning. However, the motivational role of the teacher and other factors of the education process should not be neglected either.

There are many possibilities to facilitate both the personalized learning experience and the teacher's approach to teaching by using new media, from simple information gathering to Internet- based projects (Dudeney and Hockly 2007). Although most teachers are aware that the process is inevitable and introduce the IT at every stage of the teaching process, some are reluctant to introduce it in their classes. Research proved that blended learning (the combination of online and face-to-face instruction) produces better results in large classes (Ketterer and Marsh 2006). The thesis by Ketterer and Marsh, that "the traditional classroom model of instruction is increasingly problematic in the face of new and emerging technologies of instruction" (Ketterer and Marsh 2005) can be only partly acceptable. Judging on the grounds of her more than thirty-year-long teaching experience, the author of this paper strongly supports a "moderate" approach as most effective in given circumstances of short and intensive teaching programmes in small groups. "Moderate" in this context denotes optimized combining electronic media with other teaching tools and methods that are all goal-centred and controlled or moderated by an enthusiastic teacher. In terms of American educational technology, this approach could be determined as a teacher focused blended model, in which the teacher partly controls the time, place and pace of teaching activities. One of my favourite slogans concerning student motivation is: "A motivated teacher produces motivated students!" Some research results confirm that with regard to achievement there are no differences between conventional and distance education (Ketterer and Marsh 2006). However, there are many arguments from the teaching practice confirming that a competent and enthusiastic teacher and an interactive classroom environment are irreplaceable as motivational factors. From my own experience, these arguments are true. 


\section{Concluding Remarks}

It is obvious that electronic media make an indispensable aid and source of information in translation teaching and the translation process itself. The moderate approach, which is strongly advocated by the author of this paper and presented on the example of the University of Osijek, Croatia, is closely correlated to the model that American teaching methodologists call "a teacher-focus blended model". The author strongly supports the attitude that Dudley-Evans and St John have expressed referring to the implementation of IT in teaching foreign languages: "Teachers should have at the same time a positive attitude towards and a healthy scepticism of these technological devices" (Dudley-Evans and St John 2007: 185). Like in many other human activities, the balanced use of different methods and approaches may also be perceived as the most appropriate methodology in teaching legal translation in the modern circumstances of rapidly evolving computer technologies and intensive international communication worldwide.

\section{References}

Bhatia, Vijay. 2004. Worlds of Written Discourse: A Genre-Based View, London: Continuum.

Busse, Dietrich. 1999. Die juristische Fachsprache als Institutionensprache am Beispiel von Gesetzen und ihrer Auslegung. In: Fachsprachen. Ein internationales Handbuch zur Fachsprachenforschung und Terminologiewissenschaft, eds. Lothar Hoffmann, Hartwig Kalverkämper and Herbert Ernst Wiegand, pp. 1382 - 1391. Berlin/New York: de Gruyter.

Dudeney, Gavin and Hockly, Nicky. 2007. How to Teach English with Technology. Essex: Pearson.

Dudley-Evans, Tony and St John, Maggie Jo. 1998. 2007. Developments in English for Specific Purposes. Cambridge: Cambridge University Press. 
Hegenbarth, Rainer. 1982. Juristische Hermeneutik und linguistische Pragmatik. Königstein: Taunus.

Kelly, Dorothy. 2005. A Handbook for Translator Trainers. Manchester: St Jerome.

Ketterer, John and Marsh, George. 2006. Re-Conceptualizing Intimacy and Distance in Instructional models. Online Journal of Distance Learning Administration, Volume IX, Number I.

Kordić, Ljubica. 2010. Elementi neformalnosti i poetičnosti u jeziku prava [Informal and Poetic Elements in the Language of Law]. Zbornik radova HDPL, pp. 175-185. Zagreb-Osijek: HDPL Filozofski fakultet Sveučilišta J.J. Strossmayera.

Kordić, Ljubica. 2015. Pravna lingvistila - sinergija jezika i prava [Legal linguistics - A Synergy of the Language and Law]. Osijek: Sveučilište Josipa Jurja Strossmayera u Osijeku, Pravni fakultet Osijek.

Larson, W. Reed and Rusk, Natalie. 2011. Intrinsic Motivation and Positive Development. In Advances in Child Development and Behavior, Vol. 41, eds. Richard M. Lerner, Jacqueline V. Lerner and Janette B. Benson, pp. 89-130. Burlington: Academic Press.

Novak, Jasminka, ed. 2003. Priručnik za prevođenje pravnih akata Europske unije /Manual for the Translation of EU Legal Acts/. Zagreb: MEI.

Nord, Christiane. 1997. Translating as a Purposeful Activity. Functionalist Approaches Explained. Manchester: St Jerome.

Prunc, Erich. 2012. Entwicklungslinien der Translationswissenschaft: Von den Asymmetrien der Sprachen zu den Asymmetrien der Macht. Frank \& Timme.

Reiß, Katharina und Vermeer, Hans. 1984. Grundlegung einer allgemeinen Translationstheorie. Tübingen: Niemeyer.

Šarčević, Susan. 1997. 2000. New Approach to Legal Translation. The Hague-London-Boston: Kluwer Law International.

Strategy of the Josip Juraj Strossmayer University 2010-2020. Osijek:

J. J. Strossmayer University Osijek.

\section{Internet sources:}

https://hpi.de/fileadmin/user_upload/fachgebiete/plattner/teaching/Mach ineTranslation/MT2015/MT01_Introduction.pdf Accessed December 3, 2017

http://cordis.europa.eu/ Accessed January 11, 2016 
Ljubica Kordić: Motivation and Electronic Media in LSP...

http://publications.europa.eu/code/en/en-000100.htm

Accessed January 11, 2016

http://ec.europa.eu/enlargement/tenders/taiex/index_en.htm. Accessed December 21, 2015

http://eur-lex.europa.eu/content/help/faq/intro.html\#top

Accessed

January 11, 2016

http://iate.europa.eu. Accessed December 28, 2015

http://www.ipex.eu/IPEXL-WEB/home/home.do. Accessed December 28, 2015

http://open-data.europa.eu/en/data/ Accessed December 21, 2015

http://ted.europa.eu/TED/main/HomePage.do. Accessed December 23, 2015

http://www.reverso.net/text_translation.aspx?lang=EN.

Accessed

December 3, 2017

http://www.systransoft.com/ Accessed December 3, 2017

http://www.freetranslation.com/ Accessed December 3, 2017 